\title{
Article
}

\section{Institutional adjustment and change at the firm level: A varieties of capitalism perspective}

Kuznetsov, Andrei and Jacob, Marcus

Available at http://clok.uclan.ac.uk/11578/

Kuznetsov, Andrei ORCID: 0000-0003-4539-0711 and Jacob, Marcus (2015) Institutional adjustment and change at the firm level: $A$ varieties of capitalism perspective. Scandinavian Journal of Management, 31 (2). pp. 165-177. ISSN $0956-5221$

It is advisable to refer to the publisher's version if you intend to cite from the work.

http://dx.doi.org/10.1016/j.scaman.2014.09.005

For more information about UCLan's research in this area go to http://www.uclan.ac.uk/researchgroups/ and search for <name of research Group>.

For information about Research generally at UCLan please go to http://www.uclan.ac.uk/research/

All outputs in CLoK are protected by Intellectual Property Rights law, including Copyright law. Copyright, IPR and Moral Rights for the works on this site are retained by the individual authors and/or other copyright owners. Terms and conditions for use of this material are defined in the policies page.

\section{CLoK}

Central Lancashire online Knowledge www.clok.uclan.ac.uk

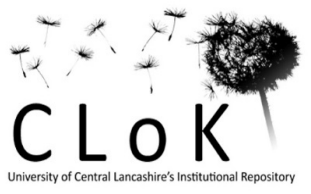




\section{INSTITUTIONAL ADJUSTMENT AND CHANGE AT THE FIRM LEVEL: A VARIETIES OF CAPITALISM PERSPECTIVE}

Andrei Kuznetsov and Marcus Jacob

Professor Andrei Kuznetsov - communicating author

Affiliation: Lancashire Business School

Address: Greenbank Building, Lancashire Business School, University of Central Lancashire, Preston, PR1 2HE, UK.

Email: AKuznetsov@uclan.ac.uk

Tel.: +44 (0) 1614380354

Dr Marcus Jacob

Address: EBS European Business School, EBS Universität f. Wirtschaft und Recht, Wiesbaden, Germany. Email: marcus.jacob@alumni.ebs.edu 


\title{
INSTITUTIONAL ADJUSTMENT AND CHANGE AT THE FIRM LEVEL: A VARIETIES OF CAPITALISM PERSPECTIVE
}

\begin{abstract}
This paper contributes to a better understanding of global corporate and industrial change at the firm level. Our focus is on convergence vs. divergence of national institutional systems. Data are drawn from a survey of German and UK firms. Our results for adaptation behaviour of British subsidiaries in Germany suggest that at the firm level the primacy of national institutions and institutional complementarity as determinants of the organizational behaviour of MNEs may be overstated. Nonetheless, evidence that German MNEs in Britain seek to choose strategic choices for which there is institutional support in the host country suggests that complementarity is functional enough to incite adjustment even in the absence of strong formal pressure. The evidence that both German and British firms seem to prefer practices characteristic of liberal market economies may pose a problem for institutional stability in Germany and generates implications for the likely pathways of institutional change.
\end{abstract}

Keywords: Global Convergence, Complementarity, Institutional Openness/ Restrictiveness, MNEhost country relations

JEL Classification: D02, F01, F55, F59, O17, P48 


\section{Introduction and problem setting}

The issue of how core institutions of advanced political economies shape the behavior of economic actors has been attracting the attention of scholars for some time now. An important debate has developed around ideas advanced by Varieties of Capitalism theory (VoCT) that emphasizes the role of the so-called social systems of production and social institutions as the source of dissimilarities between different types of national economic systems (national capitalisms) and contends that these dissimilarities generate systematic variations in corporate strategy across countries (Hall and Soskice 2001; Hollingsworth and Boyer 1997; Sabel and Zeitlin 1997). VoCT argues that pressures for convergence are counteracted by idiosyncratic national institutional arrangements, complementarily interlinked in a complex whole and persistent over time (Hall 1986; Lane 1995; Chizema and Buck 2006; Wullweber et al 2013).

The objective of this paper is to contribute to the literature on global convergence by analyzing links between intra-organizational adaptation and institutional variation across countries. A debate has erupted over how to reconcile the VoCT view on institutional complementarities and inertia with empirical observations of widespread institutional incoherence, diversity and change (Jackson and Deeg 2008; Morgan et al. 2006). The institutional complementarity hypothesis (ICH) is one of the central postulates of VoCT and a key to understanding configurations of capitalisms. It defines complementarity as a specific interplay of elements of institutional systems that creates benefits that would not exist if the configuration of the institutional environment were different (Aoki 2001; Streeck 2010). The presence of complementarity should reinforce differences between market economies and create resistance to changes of non-evolutionary nature, i.e., those provoked by pressures from outside the national institutional setup (Hertig 2006). This conclusion, however, appears to contradict reality as in the modern globalised economy the impact of the external environment as a factor of change plays a prominent role. Consequently, scholars increasingly call 
for research agendas that proceed from a mere description of different types of capitalisms towards the investigation of the pathways of institutional change at macro, meso and micro levels (Crouch et al. 2005; Deeg and Jackson 2007).

This paper attempts to respond to these calls. Going beyond existing empirical studies of complementarity that are primarily located at the macro-level (Hall and Gingerich 2009; Kenworthy 2006), we investigate complementarities at the micro level by making transnational firms the focal point of analysis. Our intention is to investigate the adaptation pattern of foreign subsidiaries from liberal market economies in coordinated market economies and vice versa. We seek to reveal how the forces of internationalization penetrate the national institutional environment in the face of resistance created by existing complementarities. We conjecture that at the micro level some coordination dimensions in host economies are more open, i.e., show more receptiveness to external influences which multinational firms bring with them, thus triggering changes that may result in the reconfiguration of institutional complementarity at the macro level over time. We infer that this may lead to conclusions regarding the global convergence of business systems and reveal the degree to which the fundamental theoretical idea of complementarity may be supported empirically.

Methodologically our objective is, in the interest of consistency, to expand VoCT theory using its own fundamental premises as a starting point of analysis. Specifically we adopt the basic bi-polar model characteristic of VoCT in its pure form that assumes the existence of just two distinct institutional settings - the liberal market economies (LME) and the coordinated market economy (CME). We also accept axiomatically the complementarity hypothesis in the form developed within this theory. Both postulates are contested in literature. The bi-polar model is often criticized for being too simplistic as in reality the distinction between capitalisms is never as clearly cut as VoCT seems to suggest. In turn, in the eyes of some authors, the treatment of the idea of complementarity, while 
intuitively very appealing, lacks necessary intellectual rigor (Crouch et al. 2005). In this paper we seek to demonstrate that some of the well publicised limitations of the concept may be rectified without leaving the platform on which the concept itself is built. Specifically, this paper seeks to reveal the possible path for the forces of internationalization to penetrate the national institutional environment in the face of resistance created by existing institutional complementarities. We conjecture that at the micro level some elements of national institutional setups in host economies are more receptive to external influences that multinational firms bring with them, thus triggering changes that ultimately result in the reconfiguration of national institutional setups as we know them today.

There is substantial literature investigating adaptation processes involving MNEs. So far analysis has been somewhat one-dimensional, centering on case study evidence, predominantly in the domain of human resource management (Ferner et al. 2001; Tüselmann et al. 2006; Von et al. 2002), but also contracting arrangements (Grimshaw and Miozzo 2006), competence development and learning practices (Geppert 2005), and work systems and manufacturing approaches (Geppert and Matten 2006). By contrast, this paper takes a holistic and quantitative approach. While qualitative studies rely on specific examples of adaptation behaviour, we seek to reveal generalizable statistical evidence of such behaviour and identify the paths through which pressures coming from internationalization may undermine the pulling force of complementarity within a national institutional setup. To achieve our objectives we apply an original 'ratio of institutional impact' (iiRatio), a novel quantitative measure of the qualitative characteristics of compliance with host country institutions.

Our findings allow identifying elements in the institutional setup that are more susceptible to change and as a result are likely to trigger systemic transformation in the production system as a whole. We 
document evidence that both German and British multinational firms seem to prefer business practices characteristic of the liberal market economy environment. This may pose a problem for institutional stability in Germany and, more generally, generates important implications for the likely pathways of institutional change and global convergence dynamics.

\section{Theoretical background and hypotheses}

For the purpose of this study, we define institutions as the rules of behaviour normatively founded and backed up by social norms and the enforcement capacities related to them (Aoki, 2001; North, 1990). Institutions represent constraints, resources and opportunities for specific sets of actors and their activities. VoCT (Hall and Soskice 2001) focuses on firms as such actors and their role in the process of economic adjustment and distinguishes five principal spheres of firm endeavor ('coordination dimensions'): corporate governance (CG); industrial relations (IR); training and education (TE); inter-firm relations (IFR), and firm-employee relations (ER). VoCT maintains that the degree of market and strategic coordination varies within a continuum of institutional systems (Hall and Gingerich 2009). At one end are LMEs, in which relations between firms and other actors are coordinated primarily through competitive markets. The prime examples are Great Britain, USA, Australia, Canada, New Zealand, and Ireland. At the other end stand CMEs, in which firms typically have greater strategic interaction with stakeholders such as suppliers, trade unions, employees, and sponsors. To this group gravitate, among others, Germany, Japan, Switzerland, Netherlands, Belgium, Austria and the Nordic countries. Figures 1 and 2 summarize distinctive characteristics of the two political economies that we scrutinize in this paper.

[Figures 1 and 2 about here] 
A major theoretical contribution of VoCT is establishing a link between prevailing institutional settings and economic outcomes. It maintains that institutional variation across nations is an important factor influencing firm behaviour and business practices. Key to VoCT and its implications is the institutional complementarity hypothesis (ICH) (Aoki 2001, Schmidt and Spindler 2002, Streeck 2010). As Höpner (2005) points out, the concept of institutional complementarity is central to the debate on the internal logics of production regimes, redirecting our attention from the effects of single institutions to interaction effects. Complementarity is generally conceived as a constellation, in which the presence (or efficiency) of one institution increases the returns (or efficiency) of the other (Hall and Soskice 2001), and/or mitigates the negative effects that such institutions may face (Schmidt and Hryckiewicz 2006). Institutional complementarity is not a prerogative of just one particular type of capitalism: effective coordination exists in CME as well as in LME, although it is based on different principles. Figures 1 and 2 illustrate in more detail a selection of possible complementarities among the institutions in liberal and coordinated market economies.

According to VoCT, on the one hand, entrepreneurial actors are constrained by institutions and the patterns of complementarity that exist between them, but, on the other hand, they perceive institutions as resources and look for ways to make institutions work for them. As Streeck and Thelen (2005:19) put it, “...institutions are the object of ongoing skirmishing as actors try to achieve advantage by interpreting or redirecting institutions in pursuit of their goals, or by subverting or circumventing rules that clash with their interests." This suggests that the sustainability of institutions and complementarity patterns substantially depends on how well they serve the interests of relevant actors. However, in its standard form VoCT does not deal with the issue of institutional change explicitly as well as it does not scrutinize specifically situations in which companies establish branches in an institutional environment that contrasts with the environment of their home country. 
In principle, foreign branches of MNEs may either emulate their parent companies or adopt the behavioural pattern prevalent in the host economy, or implement a model that combines the elements of both. In line with ICH, VoCT gives a general indication as to which pattern should prevail: efficiency-maximizing firms, including the subsidiaries of MNCs, will gravitate toward the mode of coordination for which there is maximum institutional support (Hall and Soskice 2001; Herrmann 2009). Because individual institutions are tied in a complementary fashion, such firms are likely to discover that the efficiency and strategic importance of adaptation to a particular institution depends on adaptation to the whole subsystem of complementary institutions (Kostova and Roth 2002). In summary, VoCT essentially predicts continuing cross-national divergence in the manner in which businesses operate: in pursuit of returns on institutional complementarity, multinational firms may be expected to choose to conform to the business practices of the host country rather than export their own routines, which means that firms originating in CMEs and operating in LMEs (and vice versa) will face over time weighty reasons to adapt to the institutional setting of the host country.

In reality international firms show resistance to institutional inertia in host countries as they demonstrate ability to pursue winning strategies that do not fit well within the system's logic (Hancké 2002). First, multinational enterprises (MNEs) are capable of combining strategies and practices originated in different institutional settings (Edwards et al. 2006), making it difficult to associate MNEs with a particular national typology or to imagine their institutional possibilities seriously constrained by the country of location (Beyer 2001). Second, MNEs have certain powers vis-à-vis local governments, including the option to exit (Mayer and Fluck 2005), that allow them to pressure for concessions regarding certain institutional practices. Finally, MNEs can influence institutional arrangements through mimetic isomorphism (organizations copy others located in their social system) as local firms often perceive multinationals as emblematic of international success and 
innovation. This may create a 'bandwagon effect', impelling changes on the national institutional landscape (Alvstam and Schamp 2005). As more and more firms operate internationally it may be assumed that any 'pure' forms of corporate conduct as described by VoCT will be progressively eroded over time.

As we indicated in Introduction, currently interaction between MNEs and national institutions is mostly dealt with in the literature through the analysis of individual cases. By contrast, in this paper we try to obtain systematical numerical evidence related to the premise that the practices of the foreign subsidiaries of MNEs are unlikely to be a perfect match to the dominant complementarity pattern of the host country, thus acting as a stimulus inciting institutional change in host political economies. In other words, we question the validity of the claim implicit in VoCT that all economic actors will seek maximum fit with the prevailing institutional setup. Accordingly, we challenge the following null hypothesis:

Hypothesis H0: Across all institutional dimensions in which firms resolve their coordination problems, foreign subsidiaries consistently exhibit the coordination logic for which there is institutional support in the host country.

Our alternative hypothesis reflects the view that multinational firms can actually benefit from deliberately pursuing strategies that do not fit exactly the logic of the host institutional setup, but allow some flexibility in the degree of adaptation:

Hypothesis H1: Across the institutional dimensions in which firms resolve their coordination problems, foreign subsidiaries may exhibit organizational behaviour that is in conflict with the prevailing institutional setup in the host country. 


\section{Data and methodology}

\section{The Sample}

Our analysis is based on the investigation of the operation of German subsidiaries in the UK and British subsidiaries in Germany, which we compare with the behaviour of indigenous firms as represented by their parent companies. This approach is informed by the fact that the varieties of capitalism literature uses Britain and Germany as exemplary cases of LME and CME respectively more often than any other countries (Farndale et al. 2008). The empirical foundation of our study is a postal survey of 854 British and 1,320 German subsidiaries based on the March 2006 edition of the firm register compiled by the German-British Chamber of Commerce and Industry (BGCC), the most comprehensive database of such type.

VoC centres on production regimes. However, this does not rule out non-industrial firms from examination (Hiscox and Rickard 2002). Hall and Soskice (2001:6) see firms as actors with 'capacities for developing, producing, and distributing goods and services [our italics - authors] profitably...' In the literature there are examples of extending $\mathrm{VoC}$ analysis to distribution and sales (Farndale et al. 2008) and services (Faulconbridge 2008). At the same time, VoC theory mostly ignores governmental organizations, banks and other financial institutions. Accordingly, we keep in our sample firms in such sectors as transportation, construction, agricultural, distribution, etc., but exclude financial firms and firms completely or partially owned by the government. Further 161 companies had to be taken out at a later stage because their addresses turned out to be invalid or contact persons were unavailable. Ultimately, the survey target population was set at 1,133 German subsidiaries in the UK and 594 British subsidiaries in Germany.

A pre-tested questionnaire was sent to $\mathrm{CEO}, \mathrm{COO}$ or Head of Corporate Development of the sampled subsidiary firms and enquired about business characteristics present in both subsidiary and parent 
firms. Potential respondents were assured of anonymity and confidentiality in treating their responses. A total of 200 usable replies were received, generating the response rate of 11.6 per cent. While this rate is lower than would be desired, it is consistent with typical returns on large-scale mail surveys (De Pelsmacker and Janssens 2007; Dillman 2000). We were unable to do a followup mailing to non-respondents because of the condition of anonymity.

To compensate for a relatively low response rate we paid special attention to verifying the representativeness of the responses we received. We compared the profile of respondent firms in both countries with their respective population profile in terms of the number of employees, subsidiary age and the sector of operation. For the first two parameters, the profiles proved to be very similar whilst the share of manufacturing firms among our respondents was lower than in the BGCC database (45.0 per cent against 63.8 per cent for German subsidiaries in the UK, and 17.6 per cent against 34.3 per cent for British affiliates in Germany). However, consequent analysis showed that the bias from the under-representation of manufacturing firms was such that it only strengthened the inferences from our results. One other limitation of the survey was its reliance exclusively on respondents working in subsidiaries rather than parent companies. This design was chosen because the anonymity provisions would not allow us to match parent firms with their subsidiaries. There is evidence that justifies our approach. First, the respondents were employees who, because of their position within the company (COO, CEO, Head of Corporate Development), can be expected with a great degree of certainty to be suitably cognizant of business practices of the parent firm. Second, the fact that some questions related to parent firms were left unanswered suggests that respondents were careful to provide only information that they believed to be reliable. Finally, we considered the likelihood that the nationality of the respondents (home or host country) could have affected the feedback due to differences in experience and backgrounds. We found no such evidence for the firms in our sample. 


\section{Ratio of Institutional Impact}

To test our hypotheses we employ the original 'ratio of institutional impact' (iiRatio). This ratio makes it possible to convert the qualitative characteristics of firms into a format that can be used in quantitative analysis. As a first step, we assign the value of one for every business characteristic that the VoC paradigm typesets as a feature of the coordinated market economy and the value of zero for every characteristic that it attributes to the liberal market economy. We use 25 such characteristics ${ }^{1}$, five per every major operational dimension (Table 1). We treat every dimension as a dependent variable, each bearing equal weight following the conventions of the VoCT (Gaur et al. 2007). The ratio is calculated by adding up the scores for all valid responses and then dividing the sum by the total number of valid responses for each of the five institutional dimensions. The range of the ratio for an individual dimension is therefore from zero to one. For example, if out of five characteristics constituting the category 'industrial relations' a respondent provided information about only three characteristics, which were encoded as 1,1 and 0 , the value of the $i i$ Ratio for 'industrial relations' would equal $(1+1+0): 3=0.67$. The ratio of zero across all five dimensions indicates that the business practices of the company correspond to the LME archetype, and the ratio of five - to the CME archetype.

[Table 1 about here]

When calculated for an individual firm, the ratio of institutional impact can be used as an indicator of how close firm strategies match the strategies supported by the institutional framework in this economy. For MNE subsidiaries the iiRatio serves as a measure of adaptation to the strategic choices supported by host-country institutions in each of the five coordination dimensions. Also, the iiRatio makes it possible to evaluate in quantitative terms the degree of adjustment and the coordination 
logic chosen by firms in relation to each of the five institutional dimensions explained above, rather than to describe in qualitative terms adaptation in individual business dimensions, to which prior research has been constrained. It is important to reiterate at this stage that the VoC concept in its description of the archetypical LME and CME firm synthesises the most representative features of a relevant type of capitalism, which in reality are likely to be spread across a number of firms with the consequence that the maximum and minimum ii Ratio is improbable to be shown by any particular company.

\section{Analyses and results}

\section{Measuring Adaptation and Complementarity}

We begin by examining strategic choices of indigenous firms. According to VoCT, we would expect the $i$ Ratio to demonstrate that the spread of institutionally determined parameters of firm behaviour is not entirely random. The obtained results (Figure 3) do indeed indicate the existence of some predisposition in the behaviour of parent firms in line with the $\mathrm{VoC}$ prediction. With the $i$ Ratio median value of 0.72 , firms in Germany position themselves towards the CME end of the institutional continuum. British firms on average behave quite differently. With the median iiRatio of 0.42 and the majority of firms in the 0.20 to 0.39 bracket, they exhibit strategic choices typical of LMEs. This finding demonstrates statistically the relevance of the distinction between types of institutional systems as proposed by the VoC paradigm.

[Figure 3 about here]

Next, we employ our $i$ Ratio to test our null hypothesis. We seek to reveal if the scope and direction of adaptation demonstrated by foreign subsidiaries in our sample produce a match with the profile of values characteristic of the majority of indigenous firms. Figures 4 and 5 present the outcomes of our calculation of the mean of the $i$ Ratio for each institutional dimension. We obtain four sets of means: 
one for indigenous firms in Germany (German parent firms, GP), one for indigenous firms in Britain (British parent firms, BP), one for German subsidiaries in Britain (GSinB) and one for British subsidiaries in Germany (BSinG). The results are shown in the form of two radar charts on which black lines provide the graphical representations of the current institutional environment in Germany and the UK as revealed through the pattern of the organizational behaviour of the indigenous firms in our sample. The gray lines represent the behavioural profiles of foreign subsidiaries.

[Figure 4 and Figure 5 about here]

The comparison of these profiles makes possible a number of observations. First, there is clear difference in the behavioural profile of German and British firms. Second, both German and British firms are shown to implement a mixed model of behaviour that combines elements of coordinated and liberal market archetypes. Finally, the charts demonstrate that across all five coordination dimensions foreign subsidiaries in Britain position themselves closer to the indigenous pattern than in Germany, suggesting the presence of a strong complementarity pull in Britain. By contrast, substantial differences between German indigenous firms and British subsidiaries in Germany are apparent across all five spheres. This is an important finding leading to interesting theoretical implications discussed in the next section.

Because VoCT focuses predominantly on the industrial sector, we verify our result by calculating the means for the subset of production subsidiaries only (Figures 4 and 5, dotted lines). The curves demonstrate properties similar to the sample as a whole; moreover, for German subsidiaries in Britain the behavioural pattern appears to be even more closely aligned with that of the indigenous firms. 
As the next step, we verify the results obtained through descriptive statistics and check if the depth and dynamics of adaptation processes is influenced by such parameters as industry affiliation, parent and subsidiary age, size and the subsidiary's function, as well as the relational context of parentsubsidiary interaction. A strong influence of firm and industry characteristics would cast doubt on the thesis that strategic choices made by subsidiaries in host countries are determined primarily by the coordination logic supported by the host country institutional environment.

Our dependent variable in these regressions, $D$, is the sum of differences in $i i$ Ratio between the subsidiary $\left(I_{S i}\right)$ and the typical (median) indigenous firm $\left(I_{M i}\right)$ across coordination dimensions $I-$ a simple measure of the depth of adaptation to the coordination strategies supported by host country institutions:

$$
D=\Sigma \mathrm{abs}\left(I_{S i}-I_{M i}\right) \text {, with } i=\mathrm{CG}, \mathrm{IR}, \mathrm{ER}, \mathrm{TE}, \mathrm{IFR} .
$$

$D$ takes on lower values for subsidiaries whose operations show uniformly greater alignment with the modal indigenous firm across all iiRatio dimensions.

We introduce explanatory variable firm size measured through the natural logarithm of the total number of employees in the parent firm (P_FIRMSIZE) and subsidiary (S_FIRMSIZE) at the time of survey. We also control for firm age by establishing control variables S_AGE and P_AGE, measured as the natural logarithm (to ensure a tighter spread of variables) of the number of years since the subsidiary and parent, respectively, were founded. Because non-production facilities may have a different exposure to the national institutional system comparing to production facilities, we establish the variable S_PRODUCTION that takes the value of one if the subsidiary acts as a production facility (the reference category is OTHER that includes all non-industrial facilities, e.g. research and 
development, after-sale services, distribution, etc). We also control for industry affiliation on the assumption that different industries may be part of different institutional arrangements (Herrmann, 2008) by assigning the value of one to dummy variable S_MANUF to firms in the manufacturing sector (the reference category was 'services and other'). ${ }^{2}$ In response to Kostova and Roth's (2002) research on the impact of the intensity of representation of parent company individuals in subsidiary management, we use S_REPRESENT to control for this parameter. S_REPRESENT is formed by adding one for each of the following: (a) subsidiary management is not recruited exclusively locally but at least partly installed by the parent firm, (b) parent company representatives can be found on the subsidiary's management board, (c) parent firm representatives hold line management functions in the subsidiary firm, and (d) parent company representatives are among subsidiary staff other than management.

Control variable is GERMAN_PARENT allows us to capture the effect of the country of location on variation in complementarity (Table 2, Column 3). It assumes the value of one if the subsidiary is located in Britain and the parent firm is located in Germany, and the value of zero if the subsidiary is located in Germany and the parent firm is in Britain. If the variable is statistically significant and positive, this suggests that the overall difference between subsidiaries and parent firms is greater for German MNEs than for British MNEs. Finally, we introduce the control variable PARENT_iiRatio to check that deeper subsidiary adaptation represented by lower distance D is not a spurious result in the sense that it merely reflects accidental greater similarity between how parent firms resolve their coordination problems at home and the strategic choices supported by host country institutions.

We run three regressions with dependent variable $\mathrm{D}$, one for the subsidiaries and indigenous firms in Britain (Table 2, Column 1), one for subsidiaries and indigenous firms in Germany (Column 2) and one for the composite sample of all firms (Column 3). The results confirm our earlier findings. The 
regression intercepts (CONST) demonstrate the difference in strategic choices between subsidiaries and indigenous firms when all firm and industry characteristics are set to zero. They indicate that the compound difference in $i$ Ratio between subsidiaries and modal indigenous firms is significantly smaller in the UK (0.950) than in Germany (2.934), suggesting a greater degree of adaptation on the part of the German subsidiaries to coordination strategies supported by British institutions. The presence of a smaller distance between German subsidiaries and indigenous firms in Britain is confirmed by the statistically significant and negative coefficient GERMAN_PARENT (Column 3). The regression results also show that firm characteristics such as size, age, etc. do not affect the adaptive behaviour of German subsidiaries in the UK in a statistically significant way (Column 1). In fact, the adjusted R-squared of the regression equation in Column 1 is negative signaling a weak explanatory power of firm and industry characteristics. This may be interpreted as evidence of the predominance of the local institutional framework in determining strategic choices available to foreign firms. For British subsidiaries in Germany (Column 2) the situation is similar with one exception: the relationship between subsidiary size and coordination distance D is statistically significant and negative. It suggests that bigger British subsidiaries in Germany are more likely to rely on coordination practices supported by the German institutional system. This might have to do with the fact that some German institutional norms (e.g., the formation of works councils) are only legally binding for firms above a certain threshold number of employees. Finally, contrary to conventional wisdom, we find no evidence of a greater alignment with host country institutions over time (as reflected in the insignificant coefficients for subsidiary age). Overall, the weak explanatory power of firm characteristics may be interpreted as indicating the overwhelming importance of exogenous factors for the process of institutional adaptation.

[Table 2 about here] 
Further analysis of the distribution of $D$ for subsidiaries yields interesting additional insights regarding the depth and breadth of adaptation (Table 3). The data make evident that close adaptation to host country institutions (defined as $\mathrm{D}<0.25$ ) has been the choice of many German firms in the UK. By contrast, even the closest adapters amongst British firms in Germany are much further away from the behavioural profile of indigenous firms as expressed by the $i i$ Ratio and there are generally few very close adapters.

[Table 3 about here]

\section{Robustness Tests}

We had two major concerns to deal with. The first check was for the consequences of possible nonsymmetrical, hierarchical relationships between parent and subsidiary. After studying the literature we identified two VoC coordination dimensions - inter-firm relations (IFR) and corporate governance (CG) - as those in which differences between parents and subsidiaries are likely to be most pronounced. We tested the validity of our approach by dropping in the robustness tests those elements of the IFR and CG, for which, according to the literature, a direct comparison between subsidiaries and non-subsidiaries was least appropriate. Subsequently, for IFR we retained all elements except 'cross-shareholdings with companies other than parent/subsidiary', whereas for CG only two elements were retained: 'more attention is paid to the long term objectives rather than to current earnings' and 'banks are an important source of financing'. The outcome of this test did not challenge our results.

Secondly, we addressed the concern that some of the 25 index elements that we used could be less suitable than other to discriminate between CMEs and LMEs because they might be harder to capture using large scale surveys. As a check we recalculated the $i i$ Ratios using just 15 elements most often 
used in the literature when comparing CMEs and LMEs. ${ }^{3}$ The results strongly confirmed the trends presented in the Analyses and Results section.

\section{Discussion}

Overall, our descriptive statistics suggest the presence of a strong complementarity pull in Britain deducible from the similarity in the $i$ Ratio profiles of the British indigenous firms and the German subsidiaries in the UK: across all institutional dimensions, German subsidiaries consistently exhibit the coordination logic for which there is institutional support in Britain. It is evident that the German subsidiaries are far more consistent in replicating the behaviour of local firms than the British subsidiaries the behaviour of German firms in Germany. Importantly, our multiple regression analysis, which controls for firm and industry characteristics, also indicates greater conformity of strategic choices across coordination dimensions (complementarity) of foreign subsidiaries in the UK compared to Germany. This finding may be linked to a number of possible explanations. One option is to attribute this to the desire of German subsidiaries to benefit from the advantages provided by institutional complementarity existing in the UK, to get a payback from 'joining in the game'. Another interpretation might be the phenomenon that some scholars (e.g., Institut der deutschen Wirtschaft Köln, 2000) call 'flight from the German model'. This describes the tendency of German businesses abroad to deliberately avoid retaining the modes of operation typical of their homecountry because their move abroad was motivated by the desire to escape such modes in the first place. Under both scenarios, the German subsidiaries' readiness to adapt in the absence of an obvious exogenous pressure suggests that the complementarity pull is received through market signals rather than formal rules. This is an important finding. For the first time evidence has been obtained at the micro level demonstrating that institutional complementarity is a material force determining firm behaviour that does not have to rely on special formal arrangements to be significant. 
This explanation, however, is one-sided as it does not satisfactorily explicate the behaviour of British firms in Germany. The difference between German and British subsidiaries may be a reflection of the fact that the two systems (CME and LME) are probably not symmetric with regard to how easily subsidiaries can learn to operate in them. The German system has many institutional idiosyncrasies making it more 'rigid' (Tempel 2003), prolonging the period of adaptation. By contrast, the institutional 'accessibility' of the UK allows easier and quicker adaptation. Our results, however, do not provide an unambiguous support to this assumption: while older subsidiaries and parent firms generally tend to have higher $i i$ Ratio scores, the effect is not statistically significant when controlled for other firm and industry characteristics in regression analysis (Table 2).

Another plausible reason is that, regarding some coordination dimensions, German parent companies may have exercised strategic choice, rather than subsidiaries having been forced to adapt by extrafirm factors. VoCT predicts that production subsidiaries should be engaged in institutional arbitrage by using the local institutional framework to develop competencies that the home institutional setting fail to enable. Indeed, we have established that production subsidiaries position themselves closer to indigenous firms than non-production, which supports the view that, when expanding abroad, production firms are more likely to be motivated by considerations of institutional arbitrage than other businesses because they are particularly sensitive to the differences in the local provision of such recourses as innovative capacity and skills.

However, our evidence on British subsidiaries in Germany suggests also the possibility of a different kind of institutional arbitrage: the situation in which MNEs use their access to the advantages of different national institutional systems to create a kind of quasi-institutional system within their own structure that allows subsidiaries to deviate from national institutional systems. As Morgan et al. (2006) propose, opting out of the dominant rules may create new costs and opportunities, and 
international firms, with their ready access to complementary resources on an international scale, are particularly well placed to take advantage of this. In this case, although circumventing national institutions may be not rational from the point of view of fitting into the local institutional setup, it does not contradict the institutional complementarity hypothesis as long as this behaviour can be seen as motivated by a desire to realise the gains of complementarity at the intra-firm level.

Our data provokes a question: could it be seen as supporting the view that liberal capitalism is a more 'natural' habitat for multinational firms? The answer should be negative. According to institutional theory, firms favor the institutional environment in which property rights and contracts are protected and the regulations are clear, stable and are universally enforced, providing for low transaction costs (Giannetti, 2003). In this respect there is little to separate the UK and Germany. According to the 2013 International Property Rights Index (IPRI, 2013), in terms of property rights protection and legality the German businesses environment is on par with that in the UK. In fact, the same report shows that property rights and legal and political environment indices in countries that VoCT designates as CMEs on average achieve a higher score than those described as liberal. This suggests that it would be unsound to argue, on the basis of our data at least, that a liberal institutional setup is by default more fitting for MNEs.

The differences in the behaviour of British and German subsidiaries may be fully explained only through a combination of factors, including those that may not be discovered without further and more exhaustive investigation requiring empirical inputs not available to us at the moment. However, some comments are appropriate. First, obtained results remind us that 'coordinated economy' does not necessarily mean 'economy with a higher pressure to adapt'. Evidently, 'coordination' and 'complementarity' relate to different qualities of the economy, and it is not impossible that a market mechanism alone may impose a greater degree of complementarity than the symbiosis of a market 
and public interference. Second, our results for Germany may be interpreted as evidence of the coexistence of a range of combinations of complementarities within a national economy. This is in line with theoretical findings by other researchers (e.g., Hassel 2014; Kogut et al. 2004). Thus, Kogut et al. (2004) identify several combinations of institutional traits that are sufficient for higher productivity, suggesting complementarities between certain practices, but also functional equivalence across several alternative combinations of institutions. Firms do not need to reproduce blindly a dominant receipt: foreign subsidiaries may find themselves involved in one set of complementary relations without being party to some others, which can explain to an extent our findings.

In terms of the convergence versus divergence discourse, the implications of our results are twofold. On the one hand, MNEs appear to draw upon the elements of institutional arrangements that belong to different systems of capitalism to build a preferred quasi-institutional setting of their own at the company level, perpetuating certain characteristic elements of differing institutional arrangements. On the other hand, as more and more firms operate internationally, it may be assumed that the 'pure' forms of corporate conduct as described by VoCT will be progressively eroded over time. The data also give some indication of a movement towards convergence on the LME system as LME firms appear to preserve more of their behaviour in CMEs in contrast to CME firms that appear to be eager to 'liberate' themselves from the restraints of the home system. This observation encourages us to join those scholars who, like Streeck (2009), predict that the German system may have a different configuration in one or two decades' time compared to today.

However, the ability of MNEs to stimulate changes in the national institutional arrangements is likely to depend on other characteristics of the institutional framework. One example is the degree of 'rigidity' of the institutional framework represented, in the case of Germany, by the highly regulated and formalised vocational training and employee relations. If it is high, subsidiary management 
potentially has more resources with which to resist parent company influence (Kristensen and Zeitlin 2005). Reported evidence appears to support this supposition. Schmitt (2003) has established that for US/UK subsidiaries in Germany the coverage by collective agreements and principles of codetermination was even higher than in comparable German companies. Similarly, employee communication and the presence of works councils appeared to be more inherent in the US/UK subsidiaries than in the local firms as German employees were often found unwilling to accept deviations from the institutional arrangements to which they were accustomed. According to Tempel (2003), in the two British chemical and pharmaceutical companies operating in Germany that she studied attempts to transplant some practices from their home base failed due to rigid German labor regulations and resistance of local management. The works by Liberman and Torbiörn (2000) and Peppard and Fitzgerald (1997) provide further evidence. These accounts allow to hypothesise that the impact of MNEs from liberal economies on, for example, vocational training and employee relations institutions in Germany is likely to be less pronounced than the impact that MNEs can potentially have in the UK.

\section{Concluding remarks}

This study has thrown some light on factors that influence MNEs when choosing between the adoption of host countries practices and the preservation of home-country routines. It has also set the stage for an empirical investigation of the pathways of institutional change, and gave some indication of the permissiveness of different institutional domains and likely convergence dynamics. Socioeconomic institutions cannot simply be transferred from one economy to another. VoCT, by stressing the role of national institutions and the power of institutional complementarity, puts into question the assertion that the world is drifting into a global equilibrium of business practices. Our results reveal the existence of two rivaling forces that have unequal influence on the different spheres of firm coordination. On the one hand, firms in LMEs and CMEs still exhibit significantly different strategic 
choices, confirming the existence of distinct systemic institutional forces as described by VoCT. On the other hand, our study showed that MNEs with access to resources in multiple institutional systems have considerable discretion over whether to adapt to host country institutions or not.

This study indicates that the concept of complementarity within national institutional systems may be valid as a generalization of institutional arrangements at the macro level, but at the micro level the primacy of national institutions as determinants of firm organization and behaviour may be overstated. At the firm level adaptation to the national institutional setup is not uniform across coordination dimensions and across different types of national institutional systems, indicating that MNEs are capable of challenging national institutions by making active use of both internationally and locally available resources, and thus facilitating changes in the national institutional setup. It is little surprising that firms within one economy engage in different strategies: they need to distinguish themselves from other firms in order to gain a competitive advantage. Besides, when establishing production abroad, MNEs may seek to take advantage of a blend of firm-specific capabilities and the benefits associated with the strategic choices supported by institutions in the host country.

Without doubt, due to their complexity and constant change, the interaction between local institutions and domestic and foreign firms requires further investigation. More research is needed to account for factors not include in our consideration, for example, the existence of two types of foreign subsidiaries, 'greenfields' and 'brownfields', and the influence that the harmonization of the European legislation may have on the adjustment of firms to foreign institutional contexts. Future research should also try to link the purpose of MNEs establishing foreign subsidiaries to their adaptation behaviour for additional insights beyond the quantitative analysis presented in this paper. Furthermore, the ratio of institutional impact introduced in this paper opens the perspective of a timeseries analysis of behavioural changes revealed by the subsidiaries of multinational corporations 
operating within different social systems of production - eventually allowing for even more incisive insights into convergence dynamics.

\section{References}

Aoki, M. (2001). Towards a Comparative Institutional Analysis. Cambridge, MA: MIT Press.

Alvstam, C., \& Schamp, E. (2005). Linking Industries across the World: Processes of Global Networking. Aldershot: Ashgate.

Beyer, J. (2001) 'One best way’ oder Varietät? Strategischer und organisatorischer Wandel von Großunternehmen im Prozess der Internationalisierung', Cologne: Max-Planck-Institut für Gesellschaftsforschung, Discussion Paper 01-2.

Chizema, A., \& Buck, T. (2006). Neo-institutional theory and institutional change: towards empirical tests on the "Americanization" of German executive pay. International Business Review, 15(5), $488-504$.

Crouch, C., Streeck, W., Boyer, R., Amable, B., Hall, P., \& Jackson, G. (2005). Dialogue on institutional complementarity and political economy. Socio-Economic Review, 3(2), 359-382.

De Pelsmacker, P., \& Janssens, W. (2007) Model for fair trade buying behaviour: The role of perceived quantity and quality of information and of product-specific attitudes. Journal of Business Ethics, 75(6), 361-80.

Deeg, R., \& Jackson, G. (2007). The state of the art: towards a more dynamic theory of capitalist variety’. Socio-Economic Review, 5(1), 149-179.

Dillman, D. (2000). Mail and Internet Surveys: The Tailored Design Method. (2 $\left.{ }^{\text {nd }} \mathrm{ed}\right)$. New York: John Wiley and Sons.

Edwards, T., Colling, T., \& Ferner, A. (2006). Comparative institutional analysis and the transfer of employment practices in multinational companies, Department of Management, King's College London, mimeo. 
Farndale, E., Brewster, C., \& Poutsma, E. (2008). Coordinated vs. liberal market HRM: the impact of institutionalization on multinational firms. The International Journal of Human Resource Management, 19(11), 2004-2023.

Faulconbridge, J. R. (2008). Managing the transnational law firm: A relational analysis of professional systems, embedded actors, and time-space-sensitive governance. Economic Geography, 84(2), 185-210.

Ferner, A., Quintanilla, J., \& Varul, M. (2001). Country-of-origin effects, host-country effects, and the management of HR in multinationals: German companies in Britain and Spain. Journal of World Business, 36(2), 107-127.

Gaur, A., Delios, A., \& Singh, K. (2007). Institutional environments, staffing strategies, and subsidiary performance. Journal of Management, 33(4), 611-36.

Geppert, M. (2005) Competence development and learning in British and German subsidiaries of MNCs: Why and how institutions still matter. Personnel Review, 34(2): 155-77.

Geppert, M., Matten, D., \& Williams, K. (2003). Change management in MNCs: how global convergence intertwines with national diversities. Human Relations, 56(7), 807-838.

Geppert, M., \& Matten, D. (2006). Institutional influences on manufacturing organization in multinational corporations: the cherrypicking' approach. Organization Studies, 27, 491-515.

Giannetti, M. (2003). Do better institutions mitigate agency problems? Evidence from corporate finance choices. Journal of Financial and Quantitative Analysis, 38(1), 185-212.

Grimshaw, D., \& Miozzo, M. (2006) Institutional effects on the IT outsourcing market: Analysing clients. Suppliers and staff transfer in Germany and the UK. Organization Studies, 27(9): $1229-59$.

Hall, P., \& Gingerich, D. (2009). Varieties of capitalism and institutional complementarities in the macroeconomy: an empirical assessment. British Journal of Political Science, 39(3), 449-482. 
Hall, P., \& Soskice, D. (2001). Varieties of Capitalism. The Institutional Foundations of Comparative Advantage. Cambridge: Cambridge University Press.

Hancké, B. (2002). Large Firms and Institutional Change: Industrial Renewal and Economic Restructuring in France. Oxford: Oxford University Press.

Hassel, A. (2014). The paradox of liberalization — understanding dualism and the recovery of the German political economy. British Journal of Industrial Relations, 52(1), 57-81.

Herrmann, A. (2009). One Political Economy, One Competitive Strategy? Comparing Pharmaceutical Firms in Germany, Italy, and the UK. Canada: Oxford University Press.

Hertig, G. (2006). Codetermination as a (partial) substitute for mandatory disclosure? European Business Organization Law Review, 7(1), 123-130.

Hiscox, M. J., \& Rickard, S. J. (2002). Birds of a Different Feather? Varieties of Capitalism, Factor Specificity, and Interindustry Labor Movements. Harvard University and University of California, San Diego.

Hollingsworth, J.R., \& Boyer, R. (Eds), (1997). Contemporary Capitalism: The Embeddedness of Institutions. New York: Cambridge University Press.

Höpner, M. (2005). What connects industrial relations and corporate governance? Explaining institutional complementarity. Socio-Economic Review, 3(2), 332-357.

Institut der deutschen Wirtschaft (2000). Argumente zu Unternehmensfragen No.6.

IPRI (2013). International Property Right Index. Available on http://www.internationalpropertyrightsindex.org/ranking.

Jackson, G., \& Deeg, R. (2008). From comparing capitalisms to the politics of institutional change. Review of International Political Economy, 15(4), 680-709.

Kenworthy, L. (2006). Institutional coherence and macroeconomic performance. Socio-Economic Review, 4(1), 69-91. 
Kogut, B., MacDuffie, J., \& Ragin, C. (2004). Prototypes and strategy: assigning causal credit using fuzzy sets. European Management Review, 1(2), 114-131.

Kostova, T., \& Roth, K. (2002). Adoption of an organizational practice by subsidiaries of multinational corporations: institutional and relational effects. The Academy of Management, Journal 45(1), 215-233.

Kristensen, P. H., \& Zeitlin, J. (2005). Local Players in Global Games: The Strategic Constitution of a Multinational Corporation. Oxford : Oxford University Press.

Lane, C. (1995). Industry and Society in Europe. Stability and Change in Britain, Germany and France. Aldershot: Edward Elgar.

Liberman, L., \& Torbiörn, I. (2000). Variances in staff-related management practices at eight European country subsidiaries of a global firm. The International Journal of Human Resource Management, 11(1), 37-59.

Mayer, C., \& Fluck, Z. (2005). Race to the top or bottom? Corporate governance, freedom of reincorporation and competition in law. OFRC Working Papers Series 2005fe07. Oxford Financial Research Centre.

Morgan, G., Whitley, R., \& Moen, E. (2006). Changing Capitalisms? Internationalism, Institutional Change and Systems of Economic Organization. Oxford, Oxford University Press.

North, D. C. (1990). Institutions, Institutional Change and Economic Performance. Cambridge, Cambridge University Press.

Peppard, J., \& Fitzgerald, D. (1997). The transfer of culturally-grounded management techniques: the case of business reengineering in Germany. European Management Journal, 15(4), 446-60.

Sabel, C., \& Zeitlin, J. (1997). Stories, strategies, structures, in Sabel, C. F., \& Zeitlin, J. (eds.) World of possibilities. Flexibility and Mass Production in Western Industrialization. Cambridge: Cambridge University Press. 
Schmidt, R.H., \& Spindler, G. (2002). Path dependence, corporate governance and complementarity, International Finance, 5(3): 311-33.

Schmidt, R.H., \& Hryckiewicz, A. (2006). Financial systems - importance, differences and convergence. Institute for Monetary and Financial Stability. IMFS Working Paper Series No. 4.

Schmitt, M. (2003). Deregulation of the German industrial relations system via foreign direct investment: are the subsidiaries of Anglo-Saxon MNCs a threat for the institutions of industrial democracy in Germany? Economic and Industrial Democracy, 24(3), 349-77.

Streeck, W. (2010). E pluribus unum? Varieties and commonalities of capitalism. MPIfG Discussion Paper No. 10/12.

Streeck, W., \& Thelen, K. (Eds) ( 2005). Beyond Continuity: Institutional Change in Advanced Political Economies. Oxford: Oxford University Press.

Streeck, W. (2009). Re-forming Capitalism. Institutional Change in the German Political Economy Oxford: Oxford University Press.

Tempel, A. (2003). Transfer oder Anpassung? Die Auswirkung von institutionellen Faktoren auf die Arbeitsbeziehungen in deutschen und britischen multinationalen Unternehmen, in C. Dörrenbächer, (Ed.), Modelltransfer in multinationalen Unternehmen: Strategien und Probleme grenzüberschreitender Konzernintegration. (pp. 130-150) Berlin: edition sigma.

Tempel, A., Edwards, T., Ferner, A., Muller-Camen, M., \& Wächter, H. (2006). Subsidiary responses to institutional duality. Collective representation practices of us multinationals in Germany and Britain. Human Relations 56(11), 1543-70.

Tüselmann, H., McDonald, F., \& Thorpe, R. (2006). The emerging approach to employee relations in German overseas affiliates: a role model for international operation?. Journal of World Business, 41(1), 66-80. 
Von Glinow, M., Drost, E, and Teagarden, M. (2002). Converging on IHRM best practices: lessons learned from a globally distributed consortium on theory and practice. Human Resource Management, 41(1), 123-40.

Wullweber, J., Graf, A., \& Behrens, M. (2013). Theorien der Internationalen Politischen Ökonomie. Wiesbaden: Springer Fachmedien. 


\section{Figure 1}

\section{The Five Institutional Dimensions and Complementarities in CMEs}

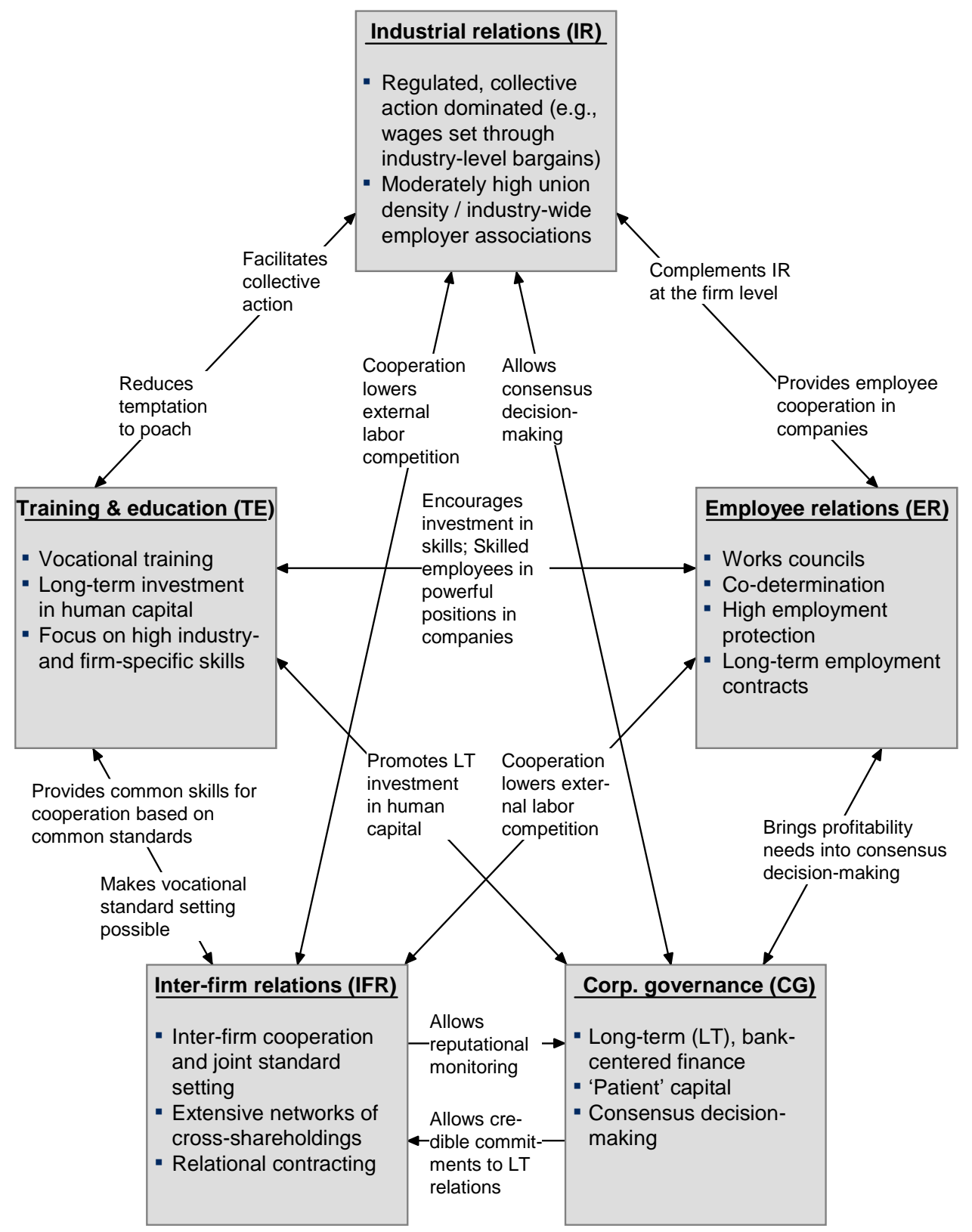

Based on Hall and Soskice (2001) 
Figure 2

\section{The Five Institutional Dimensions and Complementarities in LMEs}

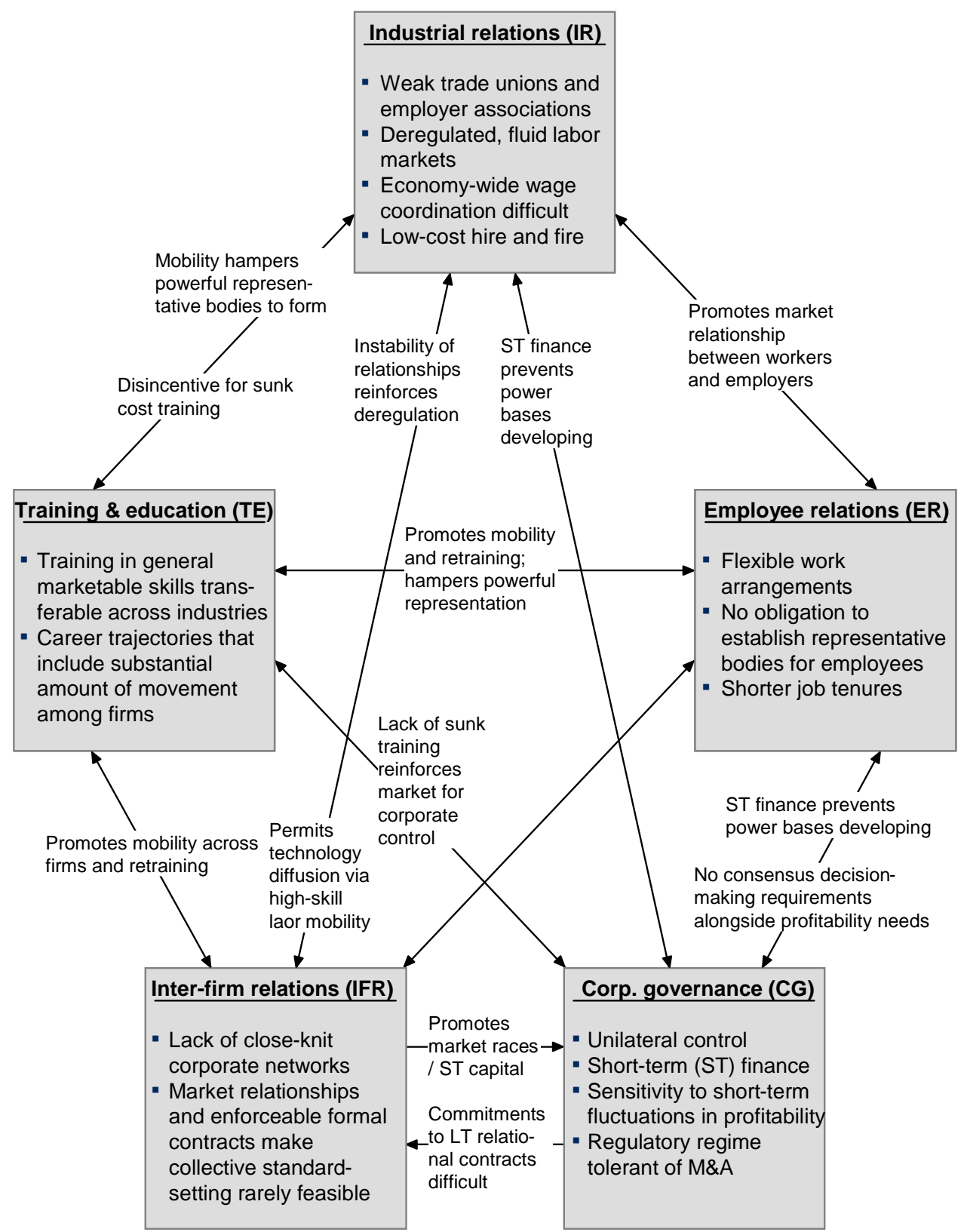

Based on Hall and Soskice (2001) 
Figure 3

Summary statistics - Indigenous firms in Germany vs. Britain (the $x$ axis shows the distribution of firms according to $i i$ Ratio; the $y$ axis shows the percentage of firms within the sample)

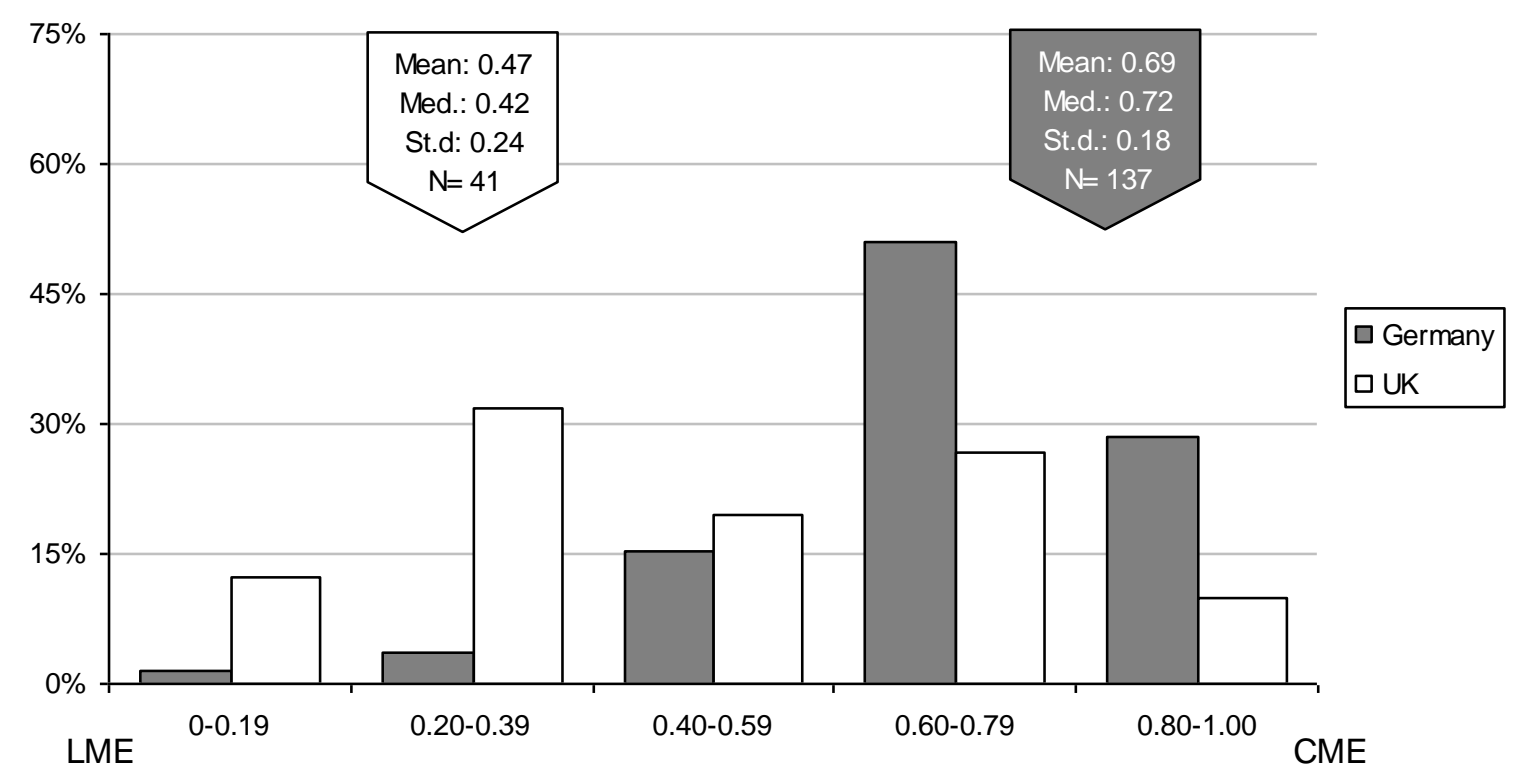


Figure 4

\section{Complementarity: Germany}

Means of the ratio of institutional impact (iiRatio) across index dimensions

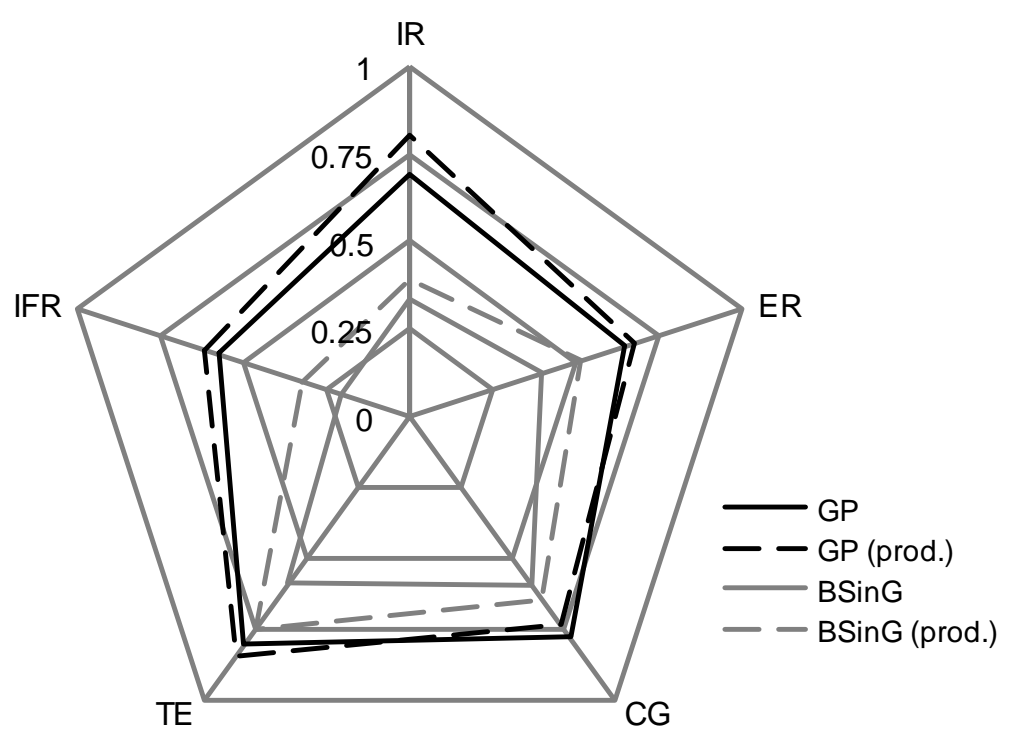


Figure 5

\section{Complementarity: UK}

Means of the ratio of institutional impact (iiRatio) across index dimensions

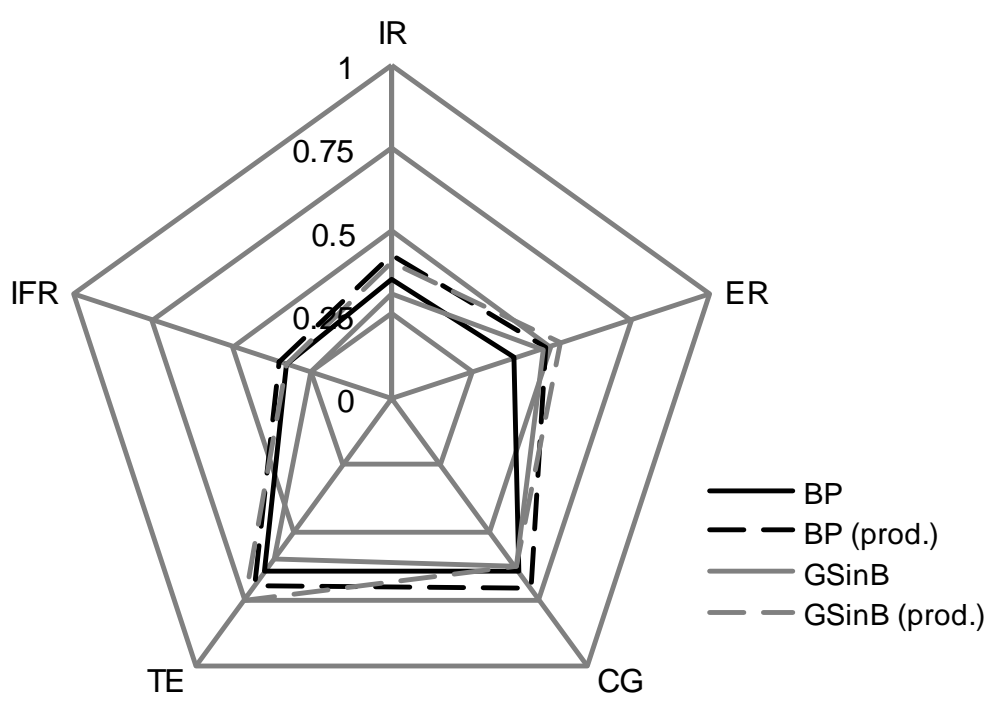


Table 1

Firm Characteristics Captured in the iiRatio and Summary Statistics

\begin{tabular}{|c|c|c|c|c|c|c|c|c|}
\hline \multirow[b]{3}{*}{ Industrial relations (IR) } & \multicolumn{2}{|c|}{ GSinB } & \multicolumn{2}{|c|}{ GP } & \multicolumn{2}{|c|}{ BSinG } & \multicolumn{2}{|c|}{$\mathrm{BP}$} \\
\hline & Yes & No & Yes & No & Yes & No & Yes & No \\
\hline & & & & & & & & \\
\hline 1. Membership in an employers' or other industry association. & 22 & 123 & 84 & 36 & 10 & 41 & 6 & 27 \\
\hline $\begin{array}{l}\text { 2. Union input and/or bargaining at the industry- and/or firm- } \\
\text { level. }\end{array}$ & 13 & 129 & 83 & 33 & 13 & 38 & 8 & 26 \\
\hline 3. Unionised workforce. & 23 & 121 & 83 & 25 & 6 & 44 & 6 & 22 \\
\hline 4. Permanent work contracts prevail over fixed-term contracts. & 126 & 17 & 88 & 19 & 37 & 13 & 22 & 4 \\
\hline 5. Employment contracts contain notice periods $\geq 90$ days. & 35 & 108 & 37 & 61 & 19 & 31 & 7 & 18 \\
\hline \multicolumn{9}{|l|}{ Employee relations (ER) } \\
\hline $\begin{array}{l}\text { 1. Active works council or comparable employee representation } \\
\text { body. }\end{array}$ & 30 & 115 & 104 & 18 & 18 & 33 & 13 & 19 \\
\hline $\begin{array}{l}\text { 2. Co-determination with employee representatives in decision- } \\
\text { making. }\end{array}$ & 27 & 117 & 58 & 53 & 14 & 36 & 9 & 22 \\
\hline 3. Employee share ownership schemes in place. & 12 & 132 & 32 & 92 & 22 & 28 & 16 & 15 \\
\hline 4. Operates performance-related pay schemes. & 98 & 43 & 87 & 28 & 40 & 11 & 27 & 6 \\
\hline 5. Operates employee consultation schemes. & 107 & 39 & 99 & 20 & 31 & 20 & 15 & 18 \\
\hline \multicolumn{9}{|l|}{ Training and education (TE) } \\
\hline 1. Special employee training schemes in place. & 88 & 54 & 112 & 10 & 29 & 19 & 23 & 12 \\
\hline 2. Systematically trains employees in firm-specific skills. & 116 & 28 & 110 & 12 & 39 & 9 & 27 & 6 \\
\hline 3. Systematically trains employees in industry-specific skills. & 93 & 47 & 101 & 18 & 27 & 20 & 23 & 8 \\
\hline 4. Poaching of employees is a significant threat to the business. & 73 & 67 & 68 & 43 & 26 & 21 & 17 & 11 \\
\hline 5. Vocational training schemes are in place. & 58 & 78 & 104 & 9 & 24 & 24 & 12 & 15 \\
\hline \multicolumn{9}{|l|}{ Corporate governance (CG) } \\
\hline $\begin{array}{l}\text { 1. More attention is paid to the long term objectives rather than } \\
\text { to current earnings. }\end{array}$ & 95 & 38 & 82 & 27 & 36 & 9 & 23 & 10 \\
\hline 2a. Banks are an important source of financing. & 19 & 122 & 48 & 61 & 10 & 36 & 7 & 5 \\
\hline 2b. Capital Markets are an important source of financing. & 3 & 137 & 28 & 81 & 5 & 41 & 15 & 19 \\
\hline 3. Investors usually commit on a long-term basis. & 82 & 35 & 84 & 17 & 15 & 24 & 19 & 10 \\
\hline $\begin{array}{l}\text { 4. Management agrees key decisions with supervisory boards } \\
\text { that include employees and major shareholders. }\end{array}$ & 51 & 84 & 89 & 25 & 12 & 28 & 15 & 14 \\
\hline $\begin{array}{l}\text { 5. At least one of the shareholders holds more than } 10 \% \text { of } \\
\text { voting rights. }\end{array}$ & 91 & 32 & 98 & 16 & 36 & 8 & 28 & 7 \\
\hline \multicolumn{9}{|l|}{ Inter-firm relations (IFR) } \\
\hline 1. Technology transfer with firms other than parent/subsidiary. & 49 & 90 & 73 & 37 & 7 & 39 & 8 & 20 \\
\hline $\begin{array}{l}\text { 2. Joint R\&D programmes with organizations other than } \\
\text { parent/subsidiary. }\end{array}$ & 36 & 102 & 78 & 34 & 8 & 40 & 9 & 20 \\
\hline 3. Merged with or acquired another firm in the past 3 years. & 26 & 110 & 63 & 51 & 11 & 31 & 21 & 14 \\
\hline $\begin{array}{l}\text { 4. Cross-shareholdings with companies other than } \\
\text { parent/subsidiary. }\end{array}$ & 8 & 126 & 24 & 82 & 2 & 40 & 2 & 28 \\
\hline $\begin{array}{l}\text { 5. Co-operation with external organizations in industry standard- } \\
\text { setting. }\end{array}$ & 52 & 84 & 72 & 37 & 13 & 32 & 8 & 23 \\
\hline
\end{tabular}


Table 2

WLS Regression Results for Coordination Distance $D$

\begin{tabular}{|c|c|c|c|}
\hline \multirow[b]{2}{*}{ Independent Variables } & \multicolumn{3}{|c|}{ Dependent Variable: $D$} \\
\hline & $\begin{array}{c}(1) \\
\text { German subsidiaries } \\
\text { in Britain }\end{array}$ & $\begin{array}{c}(2) \\
\text { British subsidiaries in } \\
\text { Germany }\end{array}$ & $\begin{array}{c}\text { (3) } \\
\text { Combined sample }\end{array}$ \\
\hline CONST & $0.950 * * *$ & $2.934 * * *$ & $1.769 * * *$ \\
\hline GERMAN_PARENT & & & $-0.892 * * *$ \\
\hline S_AGE & -0.034 & -0.144 & -0.010 \\
\hline P_AGE & 0.000 & 0.073 & 0.057 \\
\hline S_FIRMSIZE & -0.011 & $-0.198 * * *$ & $-0.052 *$ \\
\hline P_FIRMSIZE & -0.009 & $0.103^{*}$ & 0.013 \\
\hline S_PRODUCTION & 0.053 & -0.217 & -0.029 \\
\hline S_REPRESENT & 0.055 & -0.074 & 0.041 \\
\hline S_MANUF & -0.009 & 0.252 & -0.095 \\
\hline PARENT_iiRatio & YES & YES & NO \\
\hline $\mathrm{N}$ & 107 & 32 & 152 \\
\hline Adjusted $\mathrm{R}^{2}$ & -0.095 & 0.601 & 0.402 \\
\hline
\end{tabular}

NOTE. - ***, $* *$, and $*$ indicate significance at the $1 \%, 5 \%$, and $10 \%$ level, respectively. The model $\chi^{2}$ is significant at the $1 \%$ level

Table 3

Analysis of Institutional Arbitrage Motives (Distribution of D)

\begin{tabular}{ccc}
\hline $\begin{array}{c}\text { Percent below in } \\
\text { GSinB sub-sample }\end{array}$ & $\begin{array}{l}\text { Cut-off point } \\
(D)\end{array}$ & $\begin{array}{l}\text { Percent below in BSinG } \\
\text { subsample }\end{array}$ \\
\hline $1 \%$ & 0.25 & $0 \%$ \\
$12 \%$ & 0.50 & $0 \%$ \\
$30 \%$ & 0.75 & $4 \%$ \\
\hline
\end{tabular}




\section{Endnotes}

${ }^{1}$ In principle, more characteristics could be identified. However, we have deliberately opted for an index design that featured the critical characteristics of national institutional systems in accordance with $\mathrm{VoC}$ and at the same time keeps the questionnaire concise and convenient for respondents to ensure a greater response rate.

${ }^{2}$ Our results are very similar when we include dummy variables on the basis of more granular industry classifications.

${ }^{3}$ iiRatio elements 1-3, 6-8, 10-11, 15, 18-19, 21-22, 24-25 in Table 1. 